\title{
COVID-19 pandemic lockdown: effects on the air quality of South Asia
}

\author{
Ritu Kandari ${ }^{1} \cdot$ Ashwani Kumar ${ }^{2}$ (]) \\ Received: 23 June 2020 / Revised: 2 November 2020 / Accepted: 3 December 2020 / Published online: 4 February 2021 \\ (c) Society for Environmental Sustainability 2021
}

\begin{abstract}
The world is facing an unexpected, like never before, situation due to COVID-19. The measures to contain the COVID-19 pandemic are to incorporate lockdown, social distancing, disconnection, and home isolation. Lockdown was enforced by the various governments of the South Asian countries, which include non-working of all the businesses and assembling units, with limited access to the outer world pertaining to essential commodities. However, During the COVID-19 pandemic, an uncommon positive impact is noteworthy for worldwide abatement in air-contamination levels. Principally, specialists have estimated significant improvement in air quality and a remarkable decrease in concentration levels of various harmful gases like sulfur dioxide $\left(\mathrm{SO}_{2}\right)$, nitrogen dioxide $\left(\mathrm{NO}_{2}\right)$, carbon monoxide $(\mathrm{CO})$, and ozone $\left(\mathrm{O}_{3}\right)$. In this article, there is an analysis made on the impact of Covid-19 lockdown on the air quality of the South Asian region i.e. (that is) the various environmental parameters along with others namely aerosol, temperature, and particulate matter $\left(\mathrm{PM}_{2.5}, \mathrm{PM}_{10}\right)$. The work includes the refining and analysis of crude information of this present (2020) and the past year of different toxic gases and parameters of air pollutants. These have been obtained from pollution control boards of respective South Asian nations alongside information and satellite pictures from the UN Environment Program and Space Administration for correlation of various parameters. It has been observed that there is a sharp dip in the pollutant concentration in South Asia. This examination altogether will be valuable data to environmentalists and experts to make the future policies for improving air quality and the environment.
\end{abstract}

Keywords COVID-19 $\cdot$ Lockdown $\cdot$ Air quality $\cdot$ South asia $\cdot$ Self-healing nature

\section{Introduction}

As per the Wuhan Municipal Health Commission, in December 2019 China reported several cases of viral pneumonia (Huang et al. 2020; Chakraborty and Ghosh 2020). Numbers of patients with pneumonia symptoms, and a novel viral disease, Corona Virus Disease-2019 (COVID-19), was identified. On March 11, WHO declared COVID-19 as a pandemic. In South Asia, Nepal was the first country to report COVID -19 when a student returned from Wuhan to Kathmandu was found positive with COVID-19 on January 24, 2020 (Shrestha et al. 2020). In contrast, Maldives reported its first case on March 7 and was the latest

Ashwani Kumar

ashwakumar@gmail.com

1 Indira Gandhi Delhi Technical University for Women, Kashmere Gate, New Delhi, India

2 University School of Basic and Applied Sciences, Guru Gobind Singh Indraprastha University, Sec 16 C Dwarka, New Delhi, India
COVID-19 infected inductee from the South Asian region (Health Protection Agency, Maldives 2020). Following a second meeting of the Emergency Committee convened under the International Health Regulations on 30th January 2020, World Health Organisation (WHO 2020) declared COVID-19 as a contagious disease and announced a global public health emergency (WHO 2020a). Out of 7.15 million world COVID-19 cases reported till June 2020, 526,777 were from South Asia only (Worldometer COVID-19).

The highly contagious nature of the mentioned disease and various factors like mutation of the virus, considerable time taken to show symptoms, and sometimes asymptomatic and high transmissibility is putting great challenge for its treatment (Vellingiri et al. 2020; Chakraborty and Maity 2020). Considering the mentioned factors and the increasing number of patients, the World adopted lockdown. In early January 2020, the first lockdown was done by China in its Wuhan city. To avoid further spreading of the COVID-19, it established numerous quarantine centers (Wilder-Smith and Freedman 2020). In April, almost entire South Asia was under complete lockdown, 
and people were allowed to leave their house for essential commodities only, industries were closed, employees of the private sector were asked to work from home. Because of these limited human activities, the environment got a chance to heal itself (Paital et al. 2020). Pollution level in the South Asian regions was the worst (Nandasena et al. Nandasena et al. 2012; CBS Nepal 2013; EPA 2020), with Bangladesh, Pakistan, and India making it to the top five in the list of most polluted countries as mentioned in 2019 (IQAir 2019).

In 2019 among the top 10 most polluted cities, 6 were from India, and 3 were from Pakistan. Ghaziabad from India and Gujranwala from Pakistan were in first and third place. The Hotan city from China was 2nd and Dhaka from Bangladesh in 21st place (IQAir 2020). Every year around 4.2 million people die due to air pollution (Di et al. 2017). In 2019, India suffered the most pollution-linked deaths in the South Asian region, around 1.2 million, while Pakistan recorded more than one million deaths due to air pollution (GAHP 2020). Out of total pollution related deaths in South Asia, $40 \%$ are due to ambient air pollution. In 2017 the annual particulate exposure was highest in South Asia. National Ambient Air Quality Standards, India (National Ambient Air Quality Standards 2017; The Energy and Resources Institute, final report May 27, 2019) stated that out of 1.24 million deaths due to pollution, which was $12.5 \%$ of total deaths reported in $2017,77 \%$ are due to particulate exposure Particulate Matters $\left(\mathrm{PM}_{1.0}\right.$, $\mathrm{PM}_{2.5}$ ), Bangladesh reported 12.3 million deaths due to air pollution in the same year. Maldives has the lowest average of 48 premature deaths per year in the South Asia region due to polluted air exposure (WHO 2020). In 2016, the total number of deaths reported due to air pollution in Afghanistan, Bangladesh, Bhutan, India, Maldives, Nepal, Pakistan, and Sri Lanka were 17,143; 82,396; 375; $10,870,018 ; 45,21,908 ; 1,21,301$ and 5,669 respectively (WHO 2020; EMRO/WHO 2020). And the main cause was the higher particulate matter $\left(\mathrm{PM}_{2.5}\right)$ level which was above the safe limit $\left(40 \mathrm{~g} / \mathrm{m}^{3}\right)$. In this highly devastating situation, the lockdown turned out to be bliss to the suffering nature. Because of fewer human activities, fewer vehicles on the road, shutting off most of the industries, nature got the opportunity to heal itself and resulted in improved air quality in the South Asian countries. Herein, in this paper, an extensive discussion has been done on the effects of air pollution on humans, and the improvement of environmental parameters during the COVID-19 lockdown in South Asian countries is presented (Chakraborty and Maity 2020; Gautum 2020).

\section{Materials and methods}

Figure 1 explains the general methodology used to process and analyze the raw data obtained from various websites (aqicn.org; worldometers.info; iqair.com etc.) and other sources like World Health Organization (WHO 2020b, 2020c), United Nations Environment Programme (UNEP 2020), National Aeronautics and Space Administration (NASA 2020). For the determination of the impact of COVID-19 (March 2020-June 2020) on various environmental parameters governing South Asian countries' air quality.

The raw data of all 8 countries were collected and processed country-wise and analyzed by comparing it with the previous year's air quality data of South Asian countries using the Microsoft and Origin software. For comparative analysis of air quality, the data from January 2019 to June 8,2020 , was collected. Herein, the effect of various pollutants like Particulate Matters $\left(\mathrm{PM}_{2.5}, \mathrm{PM}_{10}\right.$, nitrogen dioxide $\left(\mathrm{NO}_{2}\right)$, sulfur dioxide $\left(\mathrm{SO}_{2}\right)$, carbon monoxide $(\mathrm{CO})$, ozone $\left(\mathrm{O}_{3}\right)$, hydrochlorofluorocarbons ( $\left.\mathrm{HCF}\right)$, methane emission, and the effect of temperature and humidity were also studied.

\section{Results and discussion}

On March 24, 2020, the Indian government ordered a nationwide lockdown for India's 1.3 billion people to avoid community transmission of contagious COVID-19 (Pai et al. 2020), and Other South Asian countries also imposed a
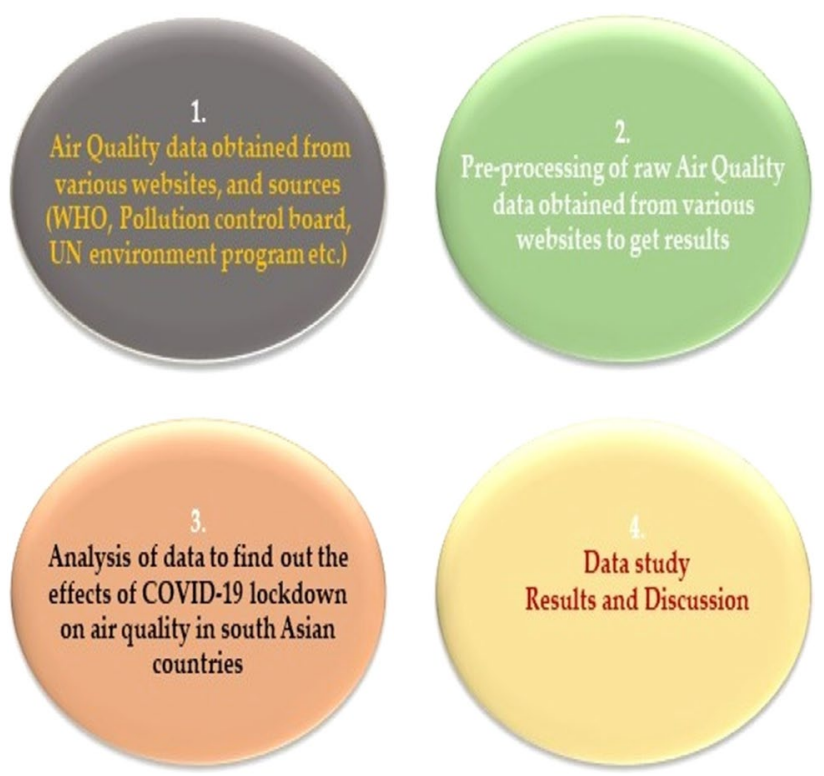

Fig.1 Adapted General methodology for study to determine the effects of COVID -19 lockdown on air quality 
complete lockdown in their respective countries. The South Asian region entered in complete lockdown in April, which resulted in fewer fossil fuels being devoured and, hence, fewer air contaminants discharged in India and other South Asian nations. From Fig. 2 it can be observed that the $\mathrm{PM}_{2.5}$ value decreased significantly in a major region of South Asia. Figures 3, 4 show the mean of the period from 2017 to 2019 and in the period of COVID-19 lockdown.

\section{Particulate matter}

Particulate Matter (PM), $\mathrm{PM}_{2.5}$ describes fine inhalable particles, with diameters that are generally $2.5 \mu \mathrm{m}$ and smaller. The observations made showed that the presence of particulate matters significantly decreased during COVID19 lockdown. Figure 2 shows that in a major portion of South Asia, the $\mathrm{PM}_{2.5}$ value decreased remarkably (Khanum et al. 2017; Luong Ly et al. 2019; Srivastava et al. 2020). According to a study comparing to the last year, Delhi observed a nearly $40 \%$ reduction in $\mathrm{PM}_{2.5}$ during the lockdown (Singh et al. 2020; Mahato et al. 2020). The $\mathrm{PM}_{2.5}$ level approached its
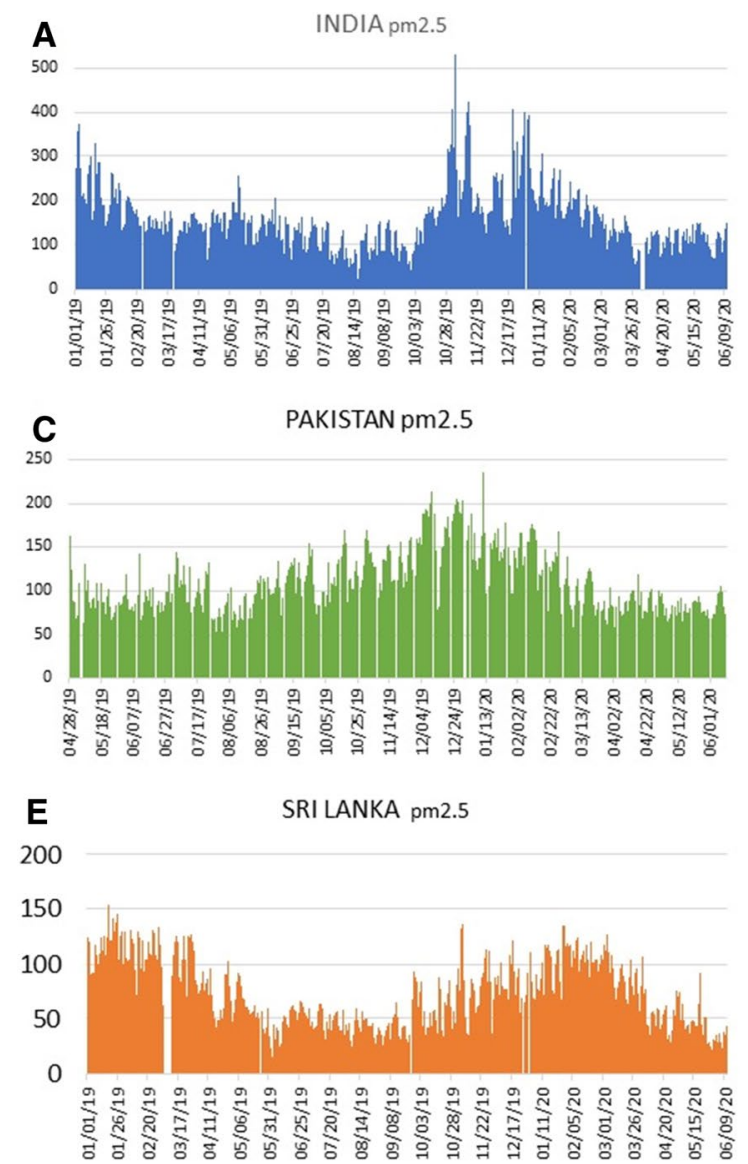

Fig. 2 Graphical demonstration of particulate matters $\left(\mathrm{PM}_{2.5}\right)\left(\mu \mathrm{g} / \mathrm{m}^{3}\right)$ level in South Asian countries in 2019-2020. Data showing the $\mathrm{PM}_{2.5}$ level in environment before and after COVID-19 Lockdown imposed normal range $\left(40 \mathrm{~g} / \mathrm{m}^{3}\right)$, which was much higher in 2017 $\left(89.9 \mathrm{~g} / \mathrm{m}^{3}\right)$ in Delhi. The National Building Research Organization (NBRO), Colombo recorded about $75 \%$ drop in $\mathrm{PM}_{2.5}$, and a $65 \%$ drop in $\mathrm{PM}_{10}$ levels were recorded in Sri Lanka compared to the air quality of the past 20 years during COVID-19 lockdown. It has been seen that the quality of air in Colombo was improved by $27 \%$ and $28 \%$ as compared with 2018 and 2019, respectively.

\section{Nitrogen dioxide $\left(\mathrm{NO}_{2}\right)$}

The most lethal oxide of nitrogen is nitrogen dioxide $\left(\mathrm{NO}_{2}\right)$. $\mathrm{NO}_{2}$ is a representative molecule for the higher molecular nitrogen oxides. Burning of fuel is a primary cause of environmental $\mathrm{NO}_{2}$. Emissions of cars, trucks and buses, power plants, and off-road equipment release $\mathrm{NO}_{2}$. The harmful impacts of breathing air with a high $\mathrm{NO}_{2}$ concentration are irritation in aviation routes in the human respiratory framework. Such exposures over a fraction of a period can initiate respiratory illnesses, especially asthma, prompting respiratory indications (such as coughing, wheezing, or
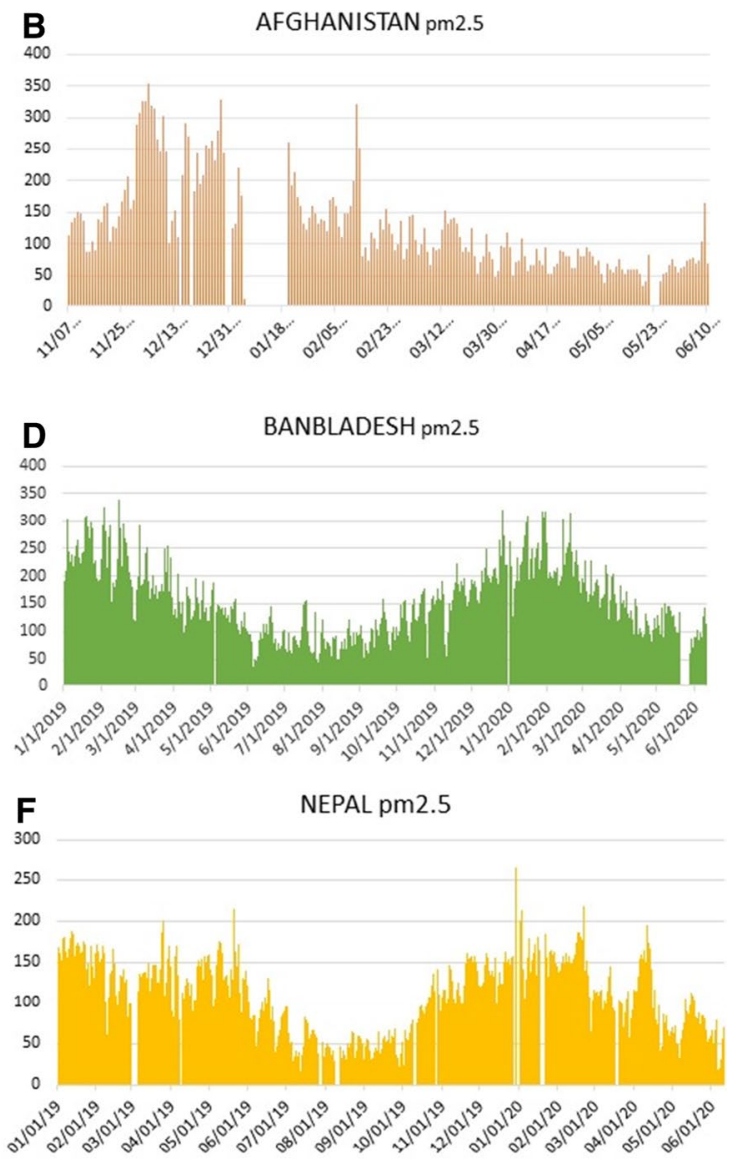

show significant improvement in term of particulate matters. (Data source: World Air Quality Index) 


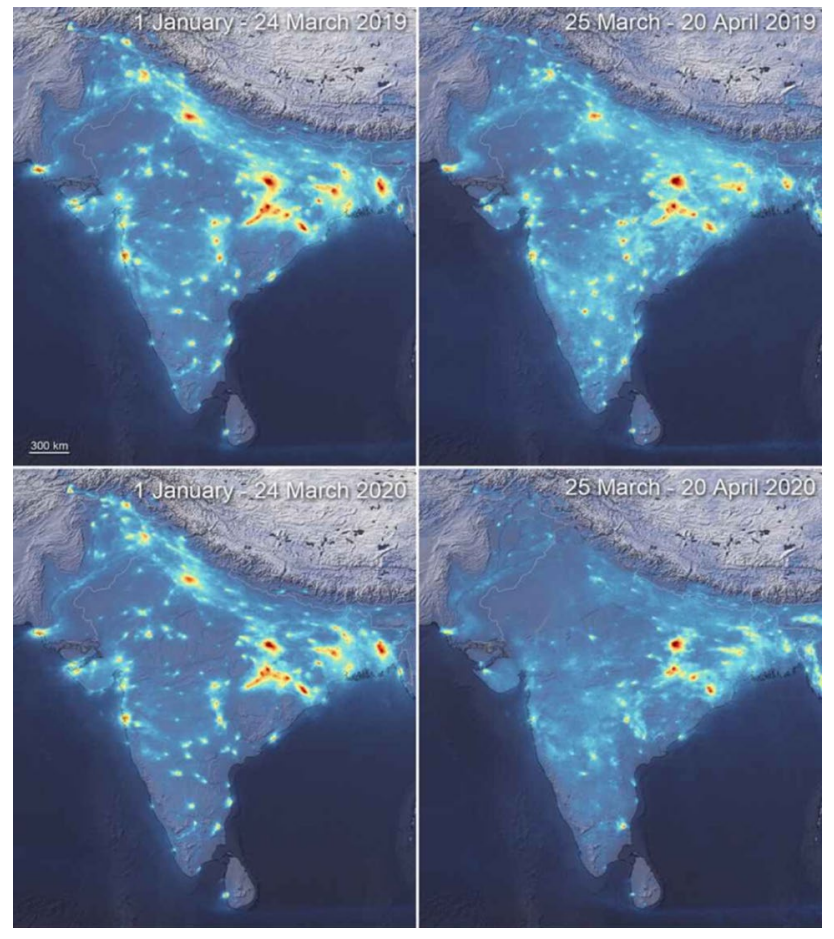

Fig. 3 Showing the fall in $\mathrm{NO}_{2}$ level in India and South Asia during COVID-19 lockdown; the images also showing a comparative study of NO2 concentration between 2019 and 2020. The $\mathrm{NO}_{2}$ level in India recorded a fall of around 45 percent during COVID-19 lockdown. (Image credit: European Space Agency) troubled breathing) (Mannucci et al. 2017). From Fig. 3, it is clear that the concentration of $\mathrm{NO}_{2}$ considerably decreased ( 30-60\%) over the maximum region of South Asia. Lahore from Pakistan recorded a significant decrement of $45 \%$ in $\mathrm{NO}_{2}$ level standing with Dhaka, Bangladesh with the same percentage of $45 \%$ decrease in $\mathrm{NO}_{2}$ level during the COVID19 lockdown. Delhi, India, recorded a remarkably lesser $\mathrm{NO}_{2}$ concentration of about 55\%. The eastern part of India, which is primarily associated with electricity generation by thermal power plants, remained much unaffected from COVID-19 lockdown with the highest $\mathrm{NO}_{2}$ levels in South Asia.

\section{Sulfur dioxide}

Sulfur dioxide $\left(\mathrm{SO}_{2}\right)$ is a colorless gas with rotten and intense odor. Its highly reactive nature is a matter of concern as it reacts with other pollutants to form more harmful compounds. The harmful pollutants formed by sulfur dioxide are sulfuric acid, sulfurous acid, and sulfate particles. A significant portion of sulfur dioxide in the environmental air comes from human-made sources. Industries during the processing of the material that contains sulfur release $\mathrm{SO}_{2}$ in the air, for example, the generation of electricity from coal, oil, or gas that contains sulfur. $\mathrm{SO}_{2}$ is also emitted from burning of fossil fuels, which contain sulfur. The harmful effects of breathing air with $\mathrm{SO}_{2}$ are respiratory tract irritation which include the nose and throat which when worsen may further cause coughing, wheezing, shortness of breath, or tightness around the chest (Brown et. al. 2003). $\mathrm{SO}_{2}$ is highly

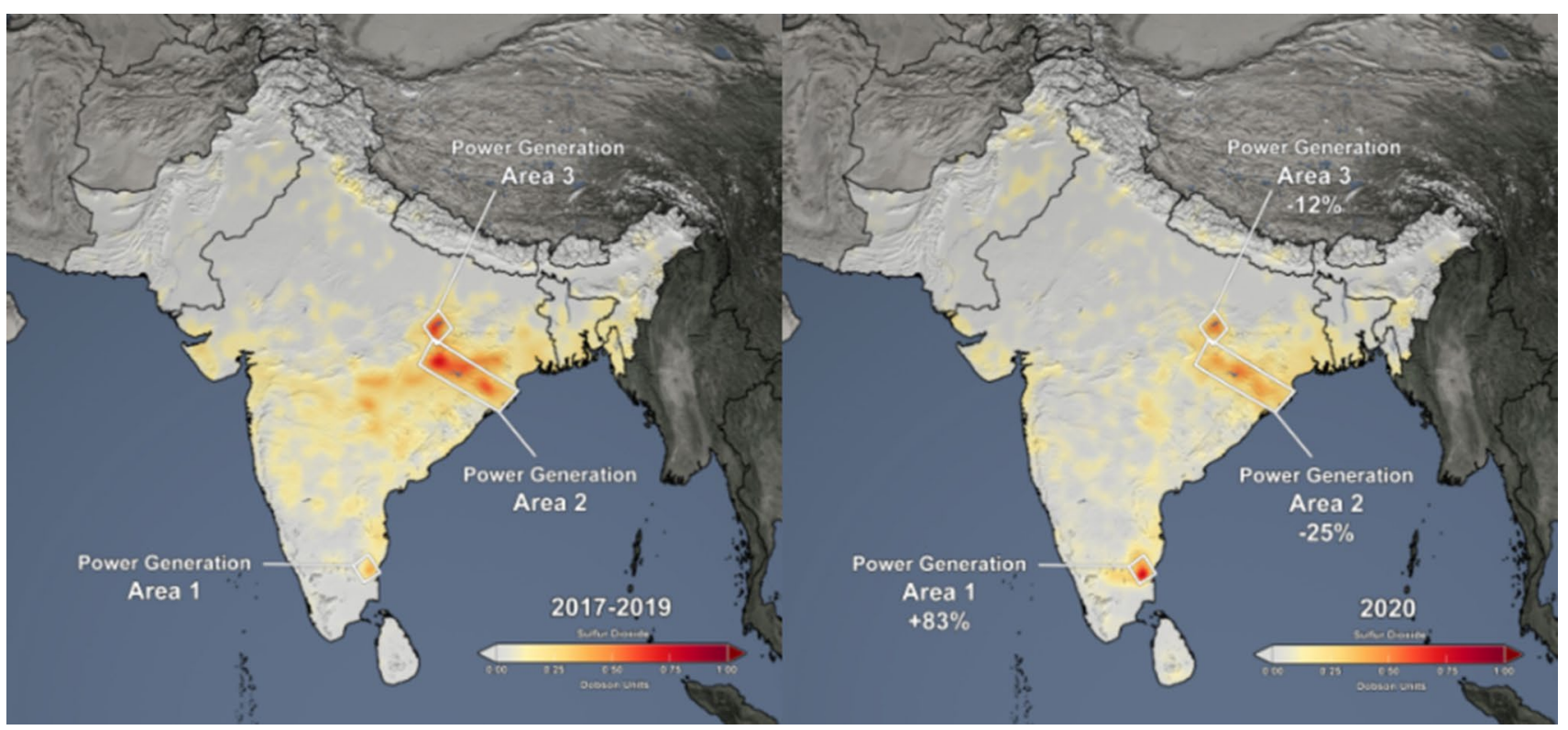

Fig. 4 Showing the fall in SO2 level in India and South Asia during COVID-19 lockdown; the images also showing a comparative study of SO2 concentrations between 2019 and 2020. In Pakistan the level of SO2 was reduced to $18.86 \mu \mathrm{g} / \mathrm{m}^{3}$, India also recorded lower values of SO2 $\left(6.0 \mu \mathrm{g} / \mathrm{m}^{3}\right)$ during COVID-19 lockdown. (Image credit: European Space Agency) 
potent, and most people would feel the worst symptoms in 10 or 15 min after breathing it in. A person with asthma or a similar type of disorder is more prone to $\mathrm{SO}_{2}$ related problems. Figure 4 indicates a comparative reduction in $\mathrm{SO}_{2}$ level in 2020. This reduction is considered a result of shut down of large scale and small-scale businesses during the COVID-19 lockdown situation in India. Electricity generation for India was down about $10 \%$ and $25 \%$ in March and April 2020, respectively. When contrasted with March and April 2019 similar kind of situation was observed in most of the South Asian region. In Islamabad, Pakistan, the level of sulfur dioxide was reduced to $18.86 \mu \mathrm{g} / \mathrm{m}^{3}$ from the pre lockdown level of $120 \mu \mathrm{g} /$ $\mathrm{m}^{3}$. A similar kind of trend was observed in Delhi, India where the value of $\mathrm{SO}_{2}$ was found $6.0 \mu \mathrm{g} / \mathrm{m}^{3}$ in COVID19 lockdown as compared to $9.90 \mu \mathrm{g} / \mathrm{m}^{3}$ before lockdown.

\section{Ozone $\left(\mathrm{O}_{3}\right)$}

Breathing air containing ozone includes the risk of asthma and may cause problems to the people who are active in outdoor activities (Paffett et al. 2015). Ozone is not the main streamline pollutant on the list but does affect the Air Quality Index. The formation and destruction of ozone takes place in nitrogen oxides (NOx) and volatile organic compounds. From Fig. 5, it can be observed that before the lockdown and after the lockdown levels of Ozone in Delhi, there is a sharp increment in the concentration of ozone during COVID 19 lockdown $(\sim 17 \%)$ (NASA 2020$)$, the daytime average was in the range of $15-40 \mu \mathrm{g} / \mathrm{m}^{3}$. After the lockdown, it was considerably higher, at $25-70 \mu \mathrm{g} / \mathrm{m}^{3}$.

\section{Carbon monoxide (CO)}

Air with a high amount of $\mathrm{CO}$ restricts the oxygen to flow through the blood and further to main organs like the heart. At exceptionally elevated levels conceivable inside or in other encased conditions, $\mathrm{CO}$ can cause dizziness, confusion, unconsciousness, and death (Rose et al. 2017). Evidence-based on ground level stations after COVID-19 lockdown, shows reductions in concentrations of four major air pollutants $\mathrm{PM}_{2.5}, \mathrm{PM}_{10}, \mathrm{NO}_{2}$, and $\mathrm{CO}$, in most of the world cities due to simultaneous lockdown. Daily CO concentration has significantly declined in South Asian cities.
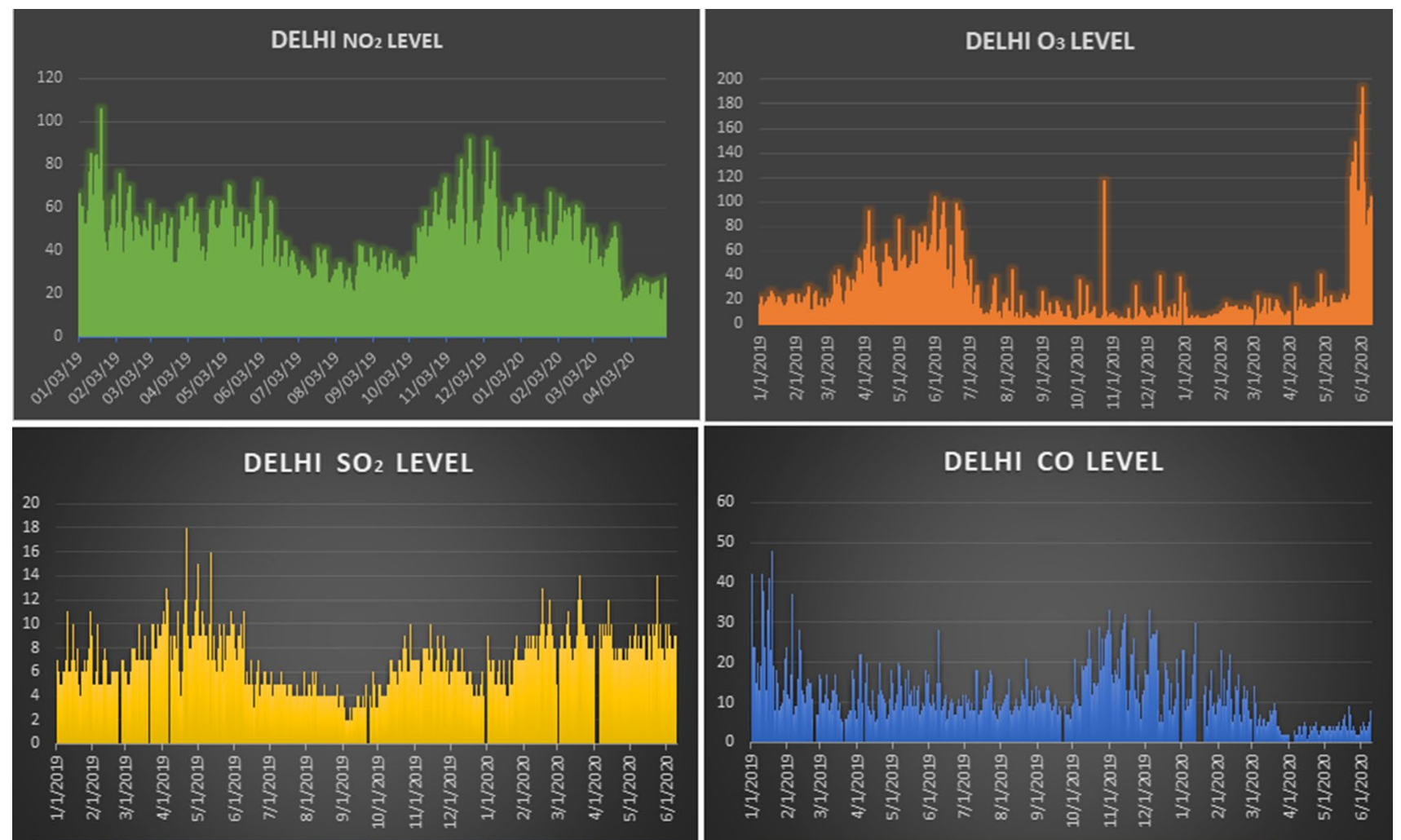

Fig. 5 Showing the changing trends of different parameters of ambient air through out the year 2019-2020 (till June 1, 2020). during COVID-19 lockdown the significant reduction in $\mathrm{NO}_{2}, \mathrm{CO}$ and

$\mathrm{SO}_{2}$ levels was recorded, whereas, there was an increased level of $\mathrm{O}_{3}$ observed in Delhi, India. (Raw Data source: World Air Quality Index) 


\section{Effects on temperature and humidity}

The nationwide COVID-19 lockdown in India and other South Asia countries was imposed to restrict the spread of Covid-19. The shutdown of factories and lesser vehicles on the road can be considered the significant reasons for the drop in air pollution levels. The major effect that can be visualized is the reduction in temperature and humidity (compared to 2019) in Delhi (Beig et al. 2020), India, (Figs. 6, 7 , respectively). Since Delhi is one of the most polluted cities in South Asia, so it is taken as a representative case. From Fig. 7, it is observed that there is a considerable reduction in temperature and humidity in Delhi after the lockdown in April 2020.

\section{Conclusion}

In this paper, the effect of COVID-19 lockdown on ambient air environment across the South Asian region, especially in India, was studied. The datasets for components of air, i.e., gases $\left(\mathrm{NO}_{2}, \mathrm{SO}_{2}, \mathrm{CO}\right.$, and $\left.\mathrm{O}_{3}\right)$ and particulate content (PM10 and PM2.5) were collected from the World Air Quality Index, WHO, Aura-OMI and various pollution control boards. For better understanding and interpretation, it was then pre-processed. By a thorough study of the comparative charts, it was established that, in comparison to the past three years, the average concentration of $\mathrm{PM}_{10}$ and $\mathrm{PM}_{2.5}$ has decreased. In Islamabad (Pakistan), $\mathrm{SO}_{2}$ was reduced remarkedly from $120 \mu \mathrm{g} / \mathrm{m}^{3}$ to $18.86 \mu \mathrm{g} /$ during the lockdown. A similar trend was found for Delhi, India, where the value of $\mathrm{SO}_{2}$ was found to be reduced
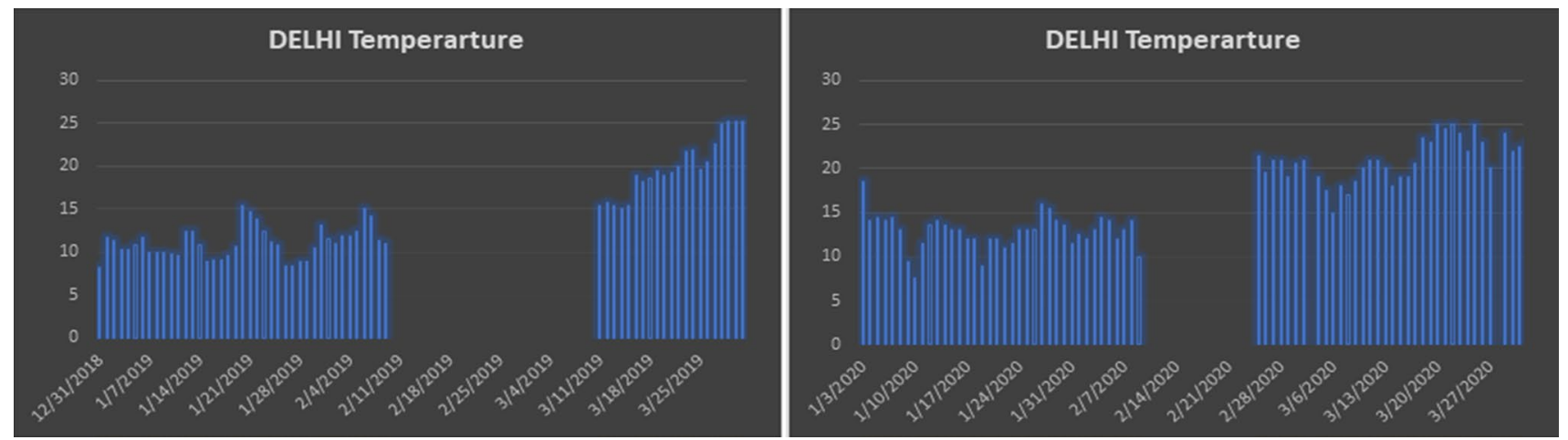

Fig. 6 Showing the changing trends in temperature of Delhi, India comparing to the 2019 trends and during COVID-19 lockdown. There was no significant change in temperature $\left(0.5-1.0^{\circ} \mathrm{C}\right)$ during COVID lockdown in Delhi, India. (Raw Data source: World Air Quality Index)
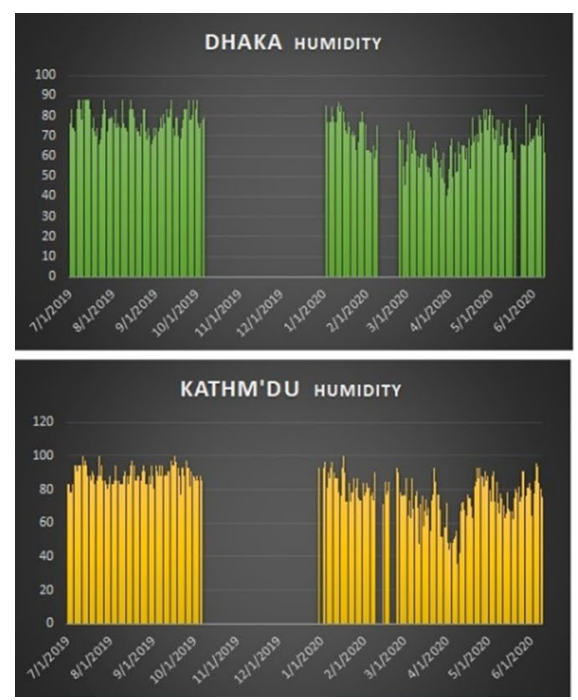
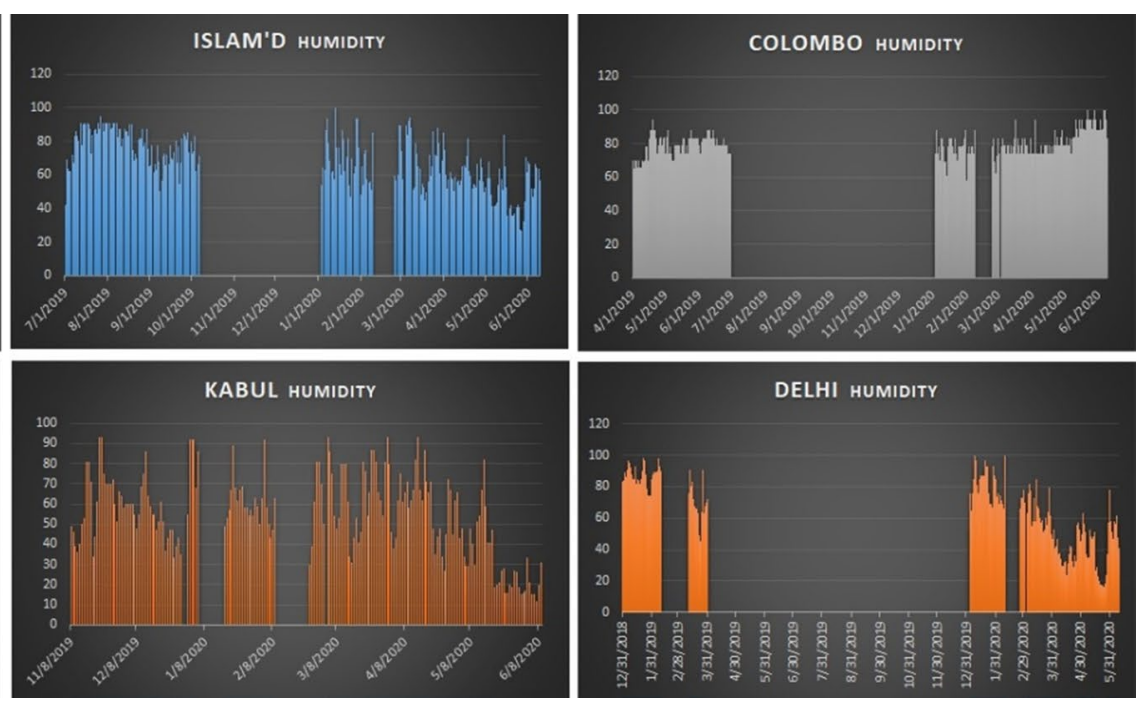

Fig. 7 Showing the changing trends in humidity in South Asian countries compared to the 2019 trends and during COVID-19 lockdown. There was an average reduction in humidity during COVID lockdown in Delhi, India. (Raw Data source: World Air Quality Index) 
to $6.0 \mu \mathrm{g} / \mathrm{m}^{3}$ from $9.90 \mu \mathrm{g} / \mathrm{m}^{3}$ during the lockdown. On the other hand, $\mathrm{O}_{3}$ didn't record critical changes throughout the year. COVID-19 has been troublesome and unprecedented for countries worldwide, but still, the lockdown has proven to be a boon for the environment in terms of air quality. It appears to open door for formulating air pollution control policies and alleviating environmental change strategies in the future.

\section{Compliance with ethical standards}

Conflicts of interest The authors declare that there is no conflict of interest regarding the publication of this manuscript.

Ethical approval Ethical approval is not required.

\section{References}

Beig G, Sahu SK, Singh V, Tikle S, Sobhana SB, Gargeva P et al (2020) Objective evaluation of stubble emission of North India and quantifying its impact on air quality of Delhi. Sci Total Environ 709:136126

Brown TP, Rushton L, Mugglestone MA, Meechan DF (2003) Health effects of a sulphur dioxide air pollution Episode. J Pub Health 25(4):369-371. https://doi.org/10.1093/pubmed/fdg083

Central Bureau of Statistics (CBS), "Environment Statistics of Nepal," 2013. https://wedocs.unep.org/bitstream/handle/20.500.11822 19406/Environment_Statistics_of_Nepal,_2013-2014Nepal_Envir onmentStatistics_2013.pdf.pdf?sequence $=3$ \&isAllowed=y

Chakraborty I, Maity P (2020) COVID-19 outbreak: migration, effects on society, global environment and prevention. Sci Total Environ 728:138882

Chakraborty T, Ghosh I (2020) Real-time forecasts and risk assessment of novel coronavirus (COVID-19) cases: a data-driven analysis Chaos. Solitons Fractals 135:109850. https://doi.org/10.1007/ s13143-019-00132-x

Di Q, Wang Y, Zanobetti A, Wang Y, Koutrakis P, Choirat C, Dominici F, Schwartz JD (2017) Air pollution and mortality in the Medicare population. N Engl J Med 376(26):2513-2522. https://doi. org/10.1056/NEJMoa1702747

EPA,2020.https://www.epa.gov/pmpollution/particulat e-matter-pmbasics.Global alliance on health and pollution (GAHP) https:// gahp.net/gahp-newsletter-updates/

Gautum S (2020) The influence of COVID-19 on air quality in India: a boon or inutile. Bull Environ Contam Toxicol 104:724. https:// doi.org/10.1007/s00128-020-02877-y

HPA, 2020. https://covid19.health.gov.mv/en/

Huang C, Wang Y, Li Xi, Li R et al (2020) Clinical features of patients infected with 2019 novel coronavirus inWuhan China. Lancet 395(10223):497-506. https://doi.org/10.1016/S0140 $-6736(20) 30183-5$

IQAir, 2020. https://www.iqair.com/world-air-quality

Khanum F, Chaudhry MN, Kumar P (2017) Characterization of fiveyear observation data of fine particulate matter in the metropolitan area of Lahore. Air Qual Atmos Health 10:725-736. https://doi. org/10.1007/s11869-017-0464-1

Luong Ly MT, Sly PD, Thai PK, Phung D (2019) Impact of ambient air pollution and wheeze associated disorders in children in Southeast Asia: a systematic review and meta-analysis. Rev Environ Health 34(2): 125-139

Mahato S, Pal S, Ghosh K (2020) Effect of lockdown amid COVID-19 pandemic on air quality of the megacity Delhi, India. Sci Total Environ 730:139086
Mannucci PM, Franchini M (2017) Health effects of ambient air pollution in developing countries. Int J Environ Res Public Health 14:1048. https://doi.org/10.3390/ijerph14091048

Nandasena $S$ et al (2012) Indoor fine particle (PM(2.5) ) pollution exposure due to secondhand smoke in selected public places of Sri Lanka. Am J Ind Med 55(12):1129-1136. https://doi.org/10.1002/ ajim. 22040

National Ambient Air Quality Standards, 2017. https://www.ksndm c.org/Uploads/Pollution.pdf

NASA,2020. https://so2.gsfc.nasa.gov/no2/no2_index.html.

Paffett ML, Zychowski KE, Sheppard L, Robertson S, Weaver JM, Lucas SN et al (2015) Ozone inhalation impairs coronary artery dilation via intracellular oxidative stress: evidence for serumborne factors as drivers of systemic toxicity. Toxicol Sci 146:244 253. https://doi.org/10.1093/toxsci/kfv093

Pai C, Bhaskar A, Rawoot B (2020) Investigating the dynamics of COVID-19 pandemic in India under lockdown. Chaos, Solitons Fractals 138:109988

Paital B (2020) Nurture to nature via COVID-19, a self-regenerating environmental strategy of environment in global context. Sci Total Environ 729:139088

Rose JJ, Wang L, Qi Xu, McTiernan CF, Shiva S et al (2017) Carbon monoxide poisoning: pathogenesis, management, and future directions of therapy. Am J Respir Crit Care Med 195:596-606

Shrestha AM, Shrestha UB, Sharma R, Bhattarai S, Tran HNT, Rupakheti M (2020) Lockdown caused by COVID-19 pandemic reduces air pollution in cities worldwide. Environ Pollut. https:// doi.org/10.31223/osf.io/edt4j

Singh P, Sarawade P, Adhikary B (2020) Carbonaceous aerosol from open burning and its impact on regional weather in South Asia. Aerosol Air Qual Res 20:419

Srivastava S, Kumar A, Bauddh K, Sagar A, Kumar GS (2020) 21-day lockdown in India Dramatically reduced air pollution indices in Lucknow and New Delhi, India. Bull Environ Contam Toxicol. https://doi.org/10.1007/s00128-020-02895-w

The Energy and Resources Institute (TERI), Final Report May 27, 2019. https://assets.publishing.service.gov.uk/media/5cf0f3b0e5 274a5eb03386da/TERI_Scoping_Study_final_report_May27 2019.pdf

United Nations Environment Programme (UNEP, 2020), https://www.unep.org/resources?f\% 5B $0 \% 5 \mathrm{D}=$ regio $\mathrm{n} \% 3 \mathrm{~A} 62 \& \mathrm{f} \% 5 \mathrm{~B} 1 \% 5 \mathrm{D}=$ topic $\% 3 \mathrm{~A} 18$

Vellingiri B, Jayaramayya K et al (2020) COVID-19: a promising cure for the global panic. Sci Total Environ 725:138277

WHO,2020,https://www.who.int/westernpacific/news/details/02-052018-one-third-of-global-air-pollution-deaths-in-South-asia

WHO,2020,https://www.who.int/docs/defaultsource/coronaviruse/situa tionreports/20200516-covid-19-sitrep-117.pdf?sfvrsn=8f562cc_2

WHO, 2020a. Rolling updates on coronavirus disease (COVID19). https://www.who.int/emergencies/diseases/novel-coronaviru s-2019/events-as-they-happen (retrieved on10.04.2020)

WHO, 2020b. Ambient (outdoor) air pollution. https://www.who.int/ news-room/factsheets/detail/ambient-(outdoor)-air-quality-andhealth

WHO, 2020c. Concentrations of fine particulate matter $\left(\mathrm{PM}_{2.5}\right)$. https ://www.who.int/gho/phe/air_pollution_pm25_concentrations/en/

Wilder-Smith A, Freedman DO (2020) Isolation, quarantine, social distancing and community containment: pivotal role for old-style public health measures in the novel coronavirus (2019-nCoV) outbreak J Travel Med 27(2): taaa020

Worldometer, 2020. https://www.worldometers.info/coronavirus/

Publisher's Note Springer Nature remains neutral with regard to jurisdictional claims in published maps and institutional affiliations. 